\title{
PELESTARIAN SUMBER DAYA TERIPANG MELALUI RESTOCKING DAN BUDI DAYA DI SULAWESI SELATAN
}

\author{
Abdul Malik Tangko*) dan Akhmad Mustafa*) \\ *) Balai Riset Perikanan Budidaya Air Payau, Maros
}

\begin{abstract}
ABSTRAK
Teripang pasir (Holothuria scabra) merupakan salah satu komoditas ekspor dari sektor perikanan yang sudah menurun produksi dan kelestarian sumber dayanya. Hal ini ditandai semakin kurangnya hasil tangkapan dan semakin kecilnya ukuran teripang yang tertangkap. Untuk meningkatkan produksi dan mempertahankan kelestariannya, perlu dilakukan upaya restocking dan budidaya di tambak. Restocking dilakukan dengan menebar benih teripang dari panti benih ke perairan dengan tujuan untuk memperkaya stok populasi teripang tersebut, sedangkan budidaya teripang di tambak, seperti di tambak tanah sulfat masam yang berasosiasi tanah gambut adalah selain bertujuan untuk meningkatkan produksi teripang, juga untuk meningkatkan produktivitas tambak tersebut yang selama ini kurang dimanfaatkan oleh pemiliknya oleh karena tingkat produktivitasnya sangat rendah bila digunakan untuk budidaya udang. Padahal jenis tambak semacam ini cukup luas di Sulawesi Selatan. Dasar pertimbangan untuk pengembangan budidaya teripang pasir di tambak sulfat masam yang berasosiasi tanah gambut adalah hasil temuan di lapangan di mana teripang pasir yang terikut pada saat panen ikan bandeng dan rumput laut mencapai bo bot 300--500 g/ekor. Untuk keberhasilan budidaya teripang pasir di tambak tersebut teknik budidaya yang diaplikasikan antara lain padat penebaran 3--5 ekor/m², pemberian pakan berupa klekap, dedak halus dicampur kotoran ayam dengan dosis dari bobot total biomassa di samping melakukan pemupukan awal dan susulan untuk menumbuhkan pakan alami berupa klekap dan plankton yang merupakan makanan utama bagi teripang. Untuk menjaga kestabilan kualitas air selama pemeliharan dilakukan penggantian air secara teratur mengikuti pola pasang surut.
\end{abstract}

KATA KUNCl: teripang pasir, produksi, restocking, teknik budidaya, tambak

\section{PENDAHULUAN}

Teripang pasir (Holothuria scabra) merupakan hewan laut yang mempunyai nilai ekonomi tinggi dan termasuk bahan ekspor andalan sektor perikanan. Oleh karena itu, kegiatan eksploitasi teripang pasir semakin meningkat dari tahun ketahun sehingga populasinya di alam secara umum semakin berkurang. Bahkan di beberapa tempat di Indonesia Bagian Timur seperti Garongkong, Kabupaten Barru, Pulau Saugi Kabupaten Pangkep, Teluk Laikang Kabupaten Takalar, dan Teluk So pura Kabupaten Kolaka yang dulunya terkenal sebagai daerah sentra sumber benih teripang di Indonesia sekarang kondisinya sudah tergolong langka (Anonim, 2007).

Salah satu faktor yang menyebabkan sulitnya memelihara atau mempertahankan kelestarian sumber daya perikanan pesisir termasuk teripang pasir yaitu adanya semacam konsep milik bersama (common property) untuk dimanfaatkan bagi kesejahteraan bersama pihak pengguna. Namun, dalam konsep milik bersama ini kadangkala dalam aplikasinya meleset dari komitmen atau kesepakatan bersama untuk mencapai kesejahteraan bersama antara masyarakat pesisir (nelayan) dan pemerintah.

Dalam konsep milik bersama seringkali terjadi kesalahpahaman akan arti dan maknanya, yaitu adanya kecenderungan pemahaman bahwa milik bersama adalah juga sifat terbuka yang menyebabkan setiap orang bebas menangkap teripang sebanyak mungkin untuk kepentingannya yang kadang-kadang tanpa mempedulikan kepentingan pihak lain dan kelestarian sumberdayanya. Apabila kondisi penangkapan atau eksploitasi semacam ini berlangsung terus dengan melibatkan banyak orang, maka pada suatu saat sumber daya teripang di Indonesia termasuk di Sulawesi Selatan akan mengalami kepunahan.

Untuk mencegah atau memperlambat proses terjadinya kepunahan sumber daya teripang tersebut, maka saatnya dilakukan upaya pengkayaan stok atau restocking di samping usaha budidaya.

\section{PRODUKSI DAN NILAI TERIPANG}

Produksi teripang di Sulawesi Selatan ada kecenderungan terjadi penurunan dari tahun ketahun, hal ini 
disebabkan permintaan pasar dan harga yang semakin meningkat sehingga kegiatan penangkapan teripang oleh nelayan juga semakin intensif dengan menggunakan berbagai cara mulai dengan cara sederhana (menyelam) hingga dengan cara modern (menggunakan jaring trawl). Sistem penangkapan teripang dengan menggunakan jaring trawl telah banyak dilakukan oleh nelayan di perairan Selat Makassar terutama di sekitar perairan Kepulauan Spermonde. Jenis teripang yang sangat diminati oleh para nelayan adalah teripang pasir (Holothuria scabra) karena jenis teripang ini harganya cukup mahal (Rp150.000,--Rp 600.000,-/kg). Penangkapan teripang dengan menggunakan jaring trawl untuk kepentingan jangka panjang sangat merugikan karena selain dapat merusak kelestarian sumber daya teripang dan jenis biota laut lainnya juga dapat merusak lingkungan habitatnya. Berdasarkan informasi dari para nelayan penangkap teripang yang menggunakan jaring trawl tersebut bahwa jumlah teripang yang tertangkap pada setiap trip penangkapan mencapai sekitar 30--50 ekor/unit alat tangkap di samping berbagai jenis ikan campuran lainnya. Dengan merajalelanya penangkapan teripang dengan menggunakan jaring trawl tersebut menyebabkan sumber daya teripang di perairan Sulawsi Selatan ada kecenderungan telah mengalami penurunan, hal ini dapat diketahui melalui data produksi teripang Provinsi Sulawesi Selatan tahun 2002-2006 (Gambar 1).

Pada Gambar 1 terlihat bahwa produksi teripang di Sulawesi Selatan tertinggi pada tahun 2005 kemudian terjadi penurunan kembali pada tahun 2006 hal ini merupakan indikasi bahwa telah terjadi penurunan populasi (stok) sumber daya teripang di alam yang kemungkinan penurunan stok tersebut akan berlangsung terus bila tidak dilakukan usaha restocking dan budidaya termasuk budidaya di tambak.

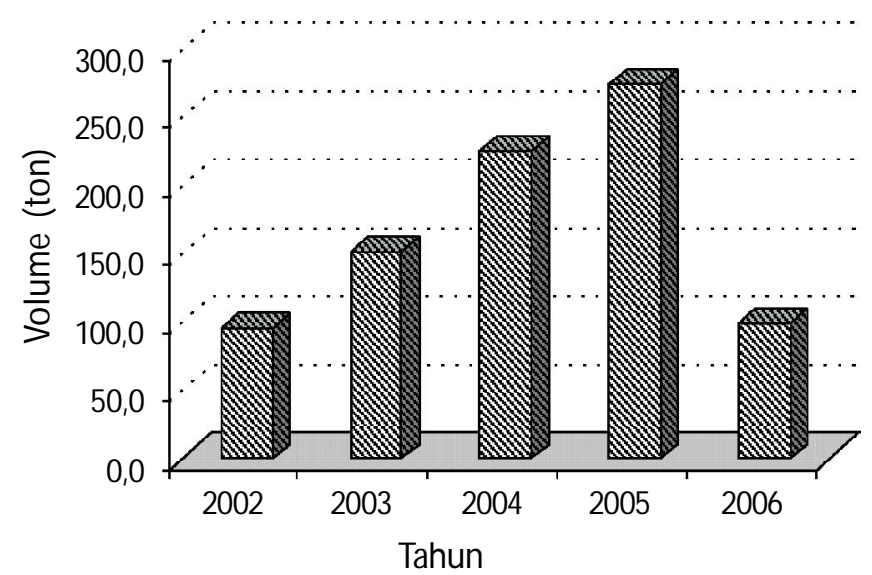

Gambar 1. Produksi teripang (ton) di Sulawesi Selatan (Anonim, 2007)
Pada Gambar 2 nampak bahwa nilai produksi teripang mengalami peningkatan dari tahun 2002 hingga tahun 2005, kemudian menurun kembali pada tahun 2006. Naik turunnya nilai teripang tersebut tergantung dari kualitas, jumlah produksi, dan nilai tukar rupiah terhadap mata uang dollar Amerika (US\$). Sedangkan nilai teripang pasir ditingkat eksportir di Sulawesi Selatan yaitu terdiri dari 4 kelas sesuai dengan kualitasnya dengan harga sekitar Rp 150.000,---6000.000,-/kg. Kriteria penentuan kualitas teripang tersebut ditentukan oleh ukuran dan tingkat kandungan kadar airnya.

\section{RESTOCKING}

Pengertian restocking teripang ialah kegiatan menebarkan benih teripang kedalam suatu perairan yang dulunya pernah ada, tetapi sekarang sudah punah, sedangkan restocking teripang pada tulisan ini adalah kegiatan penebaran ulang teripang pada habitatnya dengan tujuan untuk peningkatan populasi teripang yang sudah ada.

Ada beberapa dasar pertimbangan perlunya dilakukan pengkayaan stok atau restocking teripang tersebut yaitu: (1) Ada sumber daya teripang yang kecenderungan populasinya semakin menurun sehingga perlu diselamatkan dari kepunahan, (2) Berdasarkan sifat biologinya teripang merupakan hewan laut penghuni dasar yang menetap, namun kadang kala senang menenggelamkan diri dalam pasir atau lumpur dan mempunyai gerakan yang sangat lamban, hidup pada perairan yang relatif dangkal sehingga bila di-restocking tidak akan meninggalkan tempat restocking tersebut, (3) Perairan pesisir dan estuaria yang mempunyai tingkat kesuburan dan produktivitas tinggi cocok untuk mendukung kehidupan dan pertumbuhan teripang yang di-restocking, (4) Dengan dilakukannya restocking diharapkan dapat terjadi proses

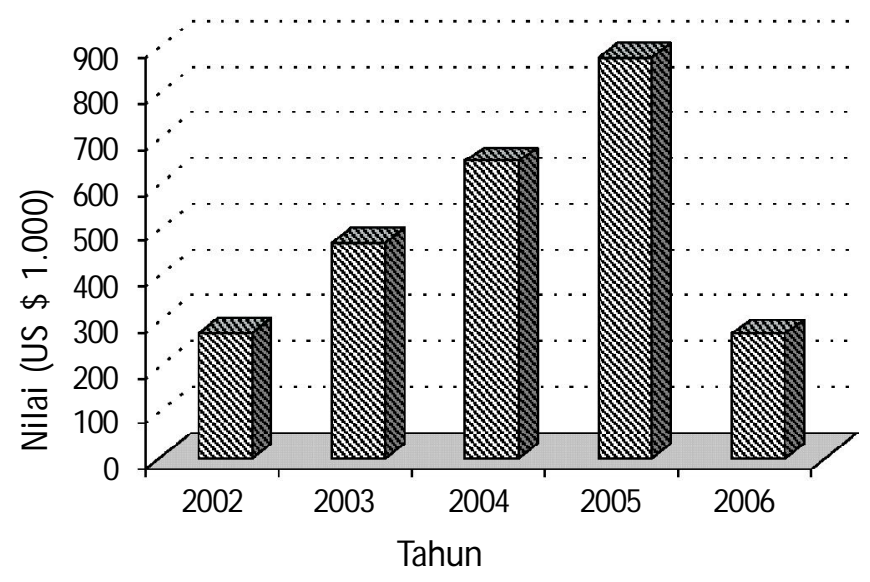

Gambar 2. Nilai produksi teripang (US\$1.000) di Sulawesi Selatan (Anonim, 2007) 
regenerasi yaitu teripang pasir yang ditebar atau direstocking yang tidak tertangkap kembali, akan menjadi induk dan memijah kembali sehingga terjadi restocking secara alami.

Restocking selain bertujuan untuk memperlambat terjadinya proses kepunahan sumberdaya teripang, juga untuk meningkatkan produktivitas sumber daya perairan pesisir setempat, melalui peningkatan populasi teripang di kawasan perairan restocking tersebut. Maka dalam kurun waktu tertentu produksi hasil tangkapan teripang nelayan setempat akan meningkat dibanding sebelum dilakukan restocking.

Meningkatnya produksi teripang setelah restocking selain dapat meningkatkan kesejahteraan masyarakat yang terlibat langsung di dalamnya, juga dapat memberikan kontribusi yang cukup besar terhadap Pendapatan Asli Daerah (PAD) setempat.

\section{KELEMBAGAAN DAN STRATEGI OPERASIONAL RESTOCKING}

Program peningkatan stok teripang melalui restocking merupakan hal baru dan masih kurang dilakukan di Indonesia, sedangkan di Sulawesi Selatan belum pernah dilakukan. Untuk keberhasilan program restocking sangat diharapkan partisipasi dari berbagai pihak terutama kelompok nelayan atau Lembaga Swadaya Masyarakat (LSM), sedangkan pihak pemerintah setempat dapat bertindak sebagai motivator atau fasilitator dan bertanggung jawab terhadap keberhasilan program tersebut.

Selain itu, pemerintah harus senantiasa melakukan pembinaan dan penyuluhan untuk menumbuhkan rasa memiliki dan kesadaran terhadap kelestarian lingkungan dan sumber daya, agar program restocking tersebut dapat berhasil dengan baik. Untuk menghindari kemungkinan terjadinya kegagalan usaha tersebut, maka sebelum dilakukan restocking perlu dilakukan perencanaan secara matang dengan melakukan survei yang mencakup kelayakan lokasi secara teknis dan kesiapan masyarakat setempat untuk menerima program restocking tersebut. Hal ini sangat penting oleh karena apabila masyarakat setempat tidak siap maka keberhasilan restocking secara maksimal kemungkinan sulit tercapai.

Salah satu persyaratan untuk keberhasilan program restocking yaitu mengurangi kegiatan penangkapan dalam jangka waktu tertentu setelah restocking dilakukan. Namun hal ini mungkin sulit untuk diterapkan bagi nelayan setempat yang memang mata pecahariannya hanya tergantung dari penangkapan teripang. Akan tetapi apabila masyarakat setempat mengerti dengan baik tujuan program restocking teripang ini, maka mereka tetap melakukan kegiatan penangkapan teripang untuk memenuhi kebutuhan hidup keluarganya dengan catatan tidak menangkap teripang yang belum mencapai ukuran konsumsi.

Menurut Cowx (1998), bahwa untuk restorasi stok (restocking for restoration) biasanya penebaran untuk pemulihan stok dilakukan setelah faktor pembatas dihilangkan atau dikurangi misalnya mengurangi pencemaran, memperbaiki kualitas air perairan, restorasi habitat dan pengendalian tekanan penangkapan setelah restocking dilakukan.

Benih teripang yang akan ditebar berasal dari pantipanti benih baik dari panti benih swasta maupun dari milik pemerintah. Benih teripang yang akan ditebar cukup tersedia baik kuantitas maupun kualitas, idealnya benih yang siap untuk ditebar ukurannya cukup besar dan seragam supaya dapat beradaptasi dengan baik pada habitat yang baru sehingga diharapkan dapat tumbuh dengan cepat dengan sintasan yang tinggi dengan waktu yang relatif singkat.

Padat penebaran yang ideal untuk restocking di perairan pantai belum ada patokannya, tetapi pada prinsipnya makin banyak benih yang ditebar maka semakin tinggi pula peluang untuk meningkatkan jumlah populasi teripang pada perairan tersebut. Indikator berhasil atau tidaknya program restocking yaitu terjadinya peningkatan hasil tangkapan nelayan menjelang beberapa bulan setelah restocking dilakukan. Untuk mengetahui seberapa jauh peningkatan produksi yang dicapai tersebut akan diketahui setelah dilakukan monitoring dan evaluasi pada 1--3 tahun berikutnya.

\section{PEMANTAUAN DAN EVALUASI PROGRAM RE- STOCKING}

Keberhasilan upaya restocking teripang tersebut antara lain dapat dilihat dari meningkatnya hasil tangkapan persatuan upaya. Pemerintah bersama kelompok-kelompok nelayan bertanggung jawab atas keberhasilan progran restocking. Selain itu, pemantauan dapat dilakukan lembaga penelitian, perguruan tinggi dan LSM.

Evaluasi keberhasilan restocking akan dilakukan setelah 1--2 tahun setelah restocking, dengan tujuan untuk mengetahui penyebab keberhasilan atau kegagalan program restocking. Hasil evaluasi berguna untuk penyempurnaan strategi dan teknik penebaran selanjutnya. Namun hasil evaluasi restocking yang akan dilakukan belum bisa ditampilkan pada tulisan ini oleh karena belum ada hasil dan baru merupakan program. 
Menurut Purnomo et al. (2001), bahwa untuk mengetahui keberhasilan atau tidaknya suatu usaha restocking nanti 1--3 tahun kemudian. Selanjutnya dikemukakan bahwa indikator keberhasilan program restocking yaitu terjadinya peningkatan produksi hasil tangkapan nelayan persatuan waktu penangkapan. Meningkatnya produksi hasil tangkapan tentunya akan diikuti meningkatnya kesejahteraan masyarakat nelayan yang terlibat langsung dalam pengelolaan atau penangkapan teripang dari hasil restocking tersebut. Apabila terjadi peningkatan kesejahteraan masyarakat setempat yang cukup signifikan setelah program restocking, maka program restocking tersebut dapat dikategorikan cukup berhasil.

\section{BUDIDAYA TERIPANG DI TAMBAK}

Budidaya teripang pasir di tambak secara komersial masih kurang dilakukan di Indonesia termasuk di Sulawesi Selatan. Namun budidaya teripang di laut yang dipelihara dalam kurungan tancap sudah banyak dilakukan baik dalam skala penelitian maupun dalam skala pengembangan di Indonesia termasuk di Sulawesi Selatan dan Sulawesi Tenggara. Kurang berkembangnya budidaya teripang di tambak disebabkan sikap pembudidaya tambak yang belum tertarik pada komoditas tersebut walaupun harganya cukup mahal bila dibandingkan harga ikan bandeng.

Salah satu faktor yang menjadi kendala dalam pengembangan budidaya teripang di tambak selama ini adalah kurang tersedianya bibit yang cukup memadai baik kuantitas maupun kualitas. Selain itu, faktor yang pakan yang tepat untuk pembesaran teripang di tambak belum ditemukan selain hanya mengandalkan kotoran ayam dan dedak halus.

Pada saat ini kedua kendala tersebut di atas sudah dapat diatasi dengan berhasilnya beberapa panti benih di Indonesia untuk memijahkan teripang pasir secara massal seperti yang terjadi pada panti benih di Bali dan Lampung. Masalah pakan untuk pembesaran teripang di tambak dapat digunakan tepung klekap dan dedak halus, selain melakukan pemupukan susulan untuk menumbuhkan klekap dan diatom di tambak.

Berdasarkan hasil survai yang dilakukan di Kecamatan Malangke Barat, Kabupaten Luwu Utara (Lutra), Sulawesi Selatan tepatnya pada posisi koordinat $120^{\circ} 2216^{\prime \prime}$ BT, $2^{\circ} 50^{\prime 2} 23^{\prime \prime}$ LS pada tahun 2007, secara tidak sengaja ditemukan banyak teripang pasir yang berukuran induk (300--500 g/ekor) yang terikut panen pada saat pembudidaya tambak panen ikan bandeng (Chanos-chanos) dan rumput laut (Gracilaria verrucosa) di tambak (Gambar 3).

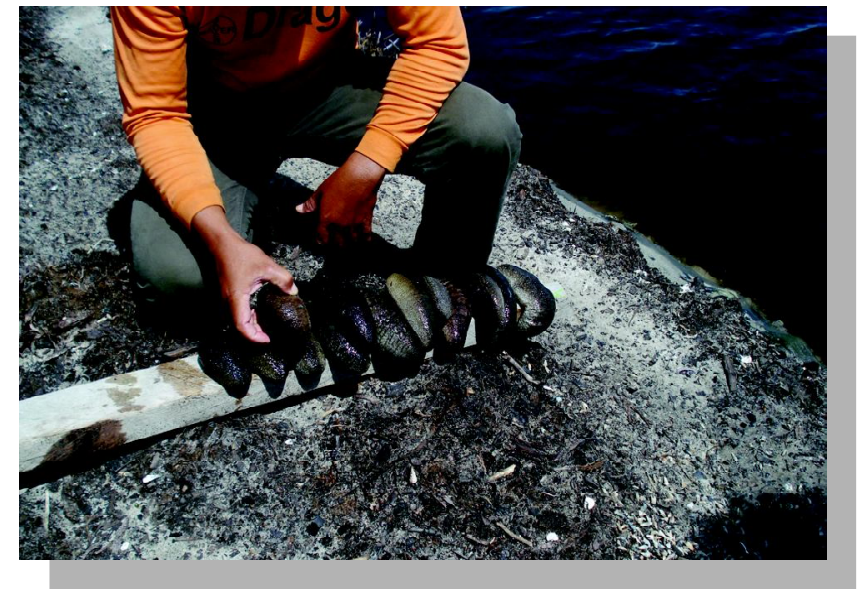

Gambar 3. Teripang pasir yang terpanen di tambak Kecamatan Malangke Barat, Kabupaten Luwu Utara, Provinsi Sulawesi Selatan

Berdasarkan informasi dari pemilik tambak tersebut bahwa teripang pasir yang terikut panen tersebut tidak ditebar dengan sengaja, tetapi masuk di tambak secara alami, sehingga ukuran awal, penebaran dan umur tidak diketahui. Selama teripang dalam tambak (pemeliharaan) tidak dilakukan pemberian pakan buatan kecuali hanya mengandalkan makanan alami (klekap) melalui pemupukan awal dan pemupukan susulan yang dilakukan oleh pembudidaya tambak. Melihat ukuran teripang yang terikut panen, tidak begitu jauh dengan ukuran teripang pasir yang dipelihara dalam kurung tancap (hampang) di laut yang dasar pasir berlumpur dan ditumbuhi lamun, yaitu mencapai ukuran 282--455 g/ekor dari ukuran awal 100-150 g/ekor selama pemeliharaan 4 bulan (Daud et al., 1994).

Teripang pasir juga ditemukan dalam tambak tanah sulfat masam yang berasosisasi dengan tanah gambut di Kabupaten Lutra. Tanah sulfat masam adalah tanah atau sedimen yang mengandung pirit, sedangkan tanah gambut adalah tanah yang mengandung bahan organik lebih besar dari 18\% Kualitas tanah tambak di mana teripang pasir ditemukan disajikan pada Tabel 1.

Dari Tabel 1 terlihat bahwa $\mathrm{pH}_{\mathrm{F}}$ ( $\mathrm{pH}$ tanah yang diukur langsung di lapangan) tanah berikisar 6,71 sampai 6,87 pada kedalaman tanah yang berbeda, sedangkan $\mathrm{pH}_{\mathrm{FOx}}(\mathrm{pH}$ tanah setelah dioksidasi dengan hidrogen peroksida $30 \%$ berkisar 1,14 sampai 1,77 . Selisih antara $\mathrm{pH}_{\mathrm{F}}$ dan $\mathrm{pH}_{\text {Fox }}$ menunjukkan nilai lebih besar dari 5 yang berarti tanah tersebut memiliki potensi kemasaman tanah. Dalam hal ini, ketika tanah terekspos dengan udara, maka pirit akan teroksidasi dan dapat menghasilkan senyawa-senyawa yang bersifat masam sehingga terjadi penurunan $\mathrm{pH}$ tanah, peningkatan kelarutan senyawa atau unsur yang bersifat 
Tabel 1. Kualitas tanah di mana teripang pasir terpanen di Kecamatan Malangke Barat, Kabupaten Luwu Utara, Provinsi Sulawesi Selatan

\begin{tabular}{lccc}
\hline \multirow{2}{*}{ Peubah } & \multicolumn{3}{c}{ Kedalaman tanah (m) } \\
\cline { 2 - 4 } & $\mathbf{0 - - 0 , 2}$ & $\mathbf{0 , 2 - - 0 , 4}$ & $\mathbf{0 , 4 - - 0 , 6}$ \\
\hline $\mathrm{pH}_{\mathrm{F}}$ & 6,87 & 6,86 & 6,71 \\
$\mathrm{pH}_{\mathrm{FOX}}$ & 1,77 & 1,14 & 1,23 \\
$\mathrm{pH}_{\mathrm{F}-\mathrm{pH}} \mathrm{FOx}$ & 5,1 & 5,74 & 5,48 \\
$\mathrm{pH}_{\mathrm{KCl}}$ & 6,53 & 6,51 & 5,36 \\
Potensial redoks (mV) & -295 & -255 & -273 \\
Bahan organik (\%) & 10,22 & 8,59 & 12,76 \\
Pirit (\%) & 0,5714 & 0,9152 & 16.563 \\
Fe (mg/L) & 1,210 & 1,172 & 1,672 \\
Al (mg/L) & 249 & 288 & 212 \\
PO4 (mg/L) & 2,1833 & 0,601 & 0,3312 \\
Pasir (\%) & 82 & - & - \\
Liat (\% & 2 & - & - \\
Debu (\%) & 16 & - & - \\
Tekstur & Pasir berlempung & - & - \\
\hline
\end{tabular}

Sumber: Mustafa et al. (2007)

toksik seperti Fe, Al dan Mn yang berdampak pula pada pengikatan unsur makro seperti fosfat yang menjadi tidak tersedia. Beberapa faktor yang menyebabkan rendahnya tingkat produktivitas tambak tanah sulfat masam tersebut antara lain adalah tingkat kemasaman tanah yang sangat tinggi ( $\mathrm{pH}<3,5$ ), adanya senyawa pirit, kandungan $\mathrm{Fe}^{2+}$, $\mathrm{Al}^{3+}, \mathrm{SO}_{4}{ }^{2-}$ tinggi dan fosfat tersedia rendah (Dent, 1986; Boyd, 1995; Aström, 1998; Mustafa \& Sammut, 2007). Sebagai akibatnya, tambak tanah sulfat masam tidak dikelola secara tepat berdampak pada produktivitas tambak yang sangat rendah terutama untuk budidaya udang seperti udang windu (Penaeus monodon) dan udang vannamei (Litopenaeus vannamei) dan ikan bandeng (Chanos chanos). Sebagai akibatnya, pembudidaya tambak di Kabupaten Lutra lebih banyak memanfaatkan tambaknya untuk budidaya rumput laut (Gracilaria verrucosa) yang lebih toleran terhadap kondisi tanah tanah sulfat masam. Melihat kenyataan yang ada, menunjukkan bahwa teripang pasir juga dapat tumbuh dengan baik pada tanah tambak tanah sulfat masam yang berasosiasi dengan tanah gambut, dengan bahan organik yang berkisar 8,59\%sampai $12,76 \%$ Tekstur tanah tambak termasuk pasir berlempung dan sesuai dengan namanya, yaitu teripang pasir, maka tekstur tanah tambak dapat mendukung kondisi habitat yang diinginkan oleh teripang pasir tersebut (Gambar 4).

Kualitas air tambak di mana teripang pasir ditemukan di tambak Kecamatan Malangke Barat dapat dilihat pada Tabel 2. Pada musim kemarau, terlihat bahwa suhu,

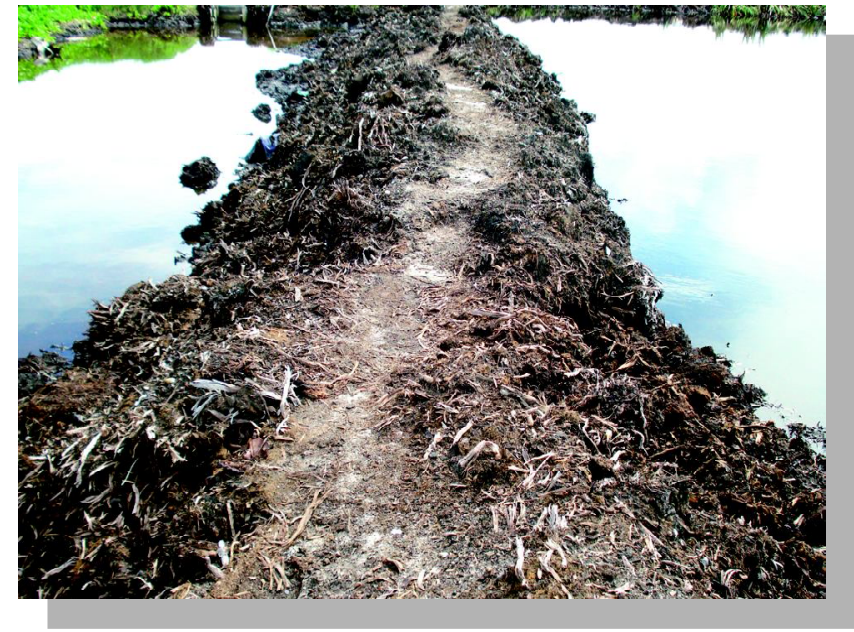

Gambar 4. Kondisi tambak di mana teripang pasir terpanen di Kecamatan Malangke Barat, Kabupaten Luwu Utara, Provinsi Sulawesi Selatan

Tabel 2. Kualitas air tambak pada musim hujan dan kemarau di mana teripang pasir terpanen di Kecamatan Malangke Barat, Kabupaten Luwu Utara, Provinsi Sulawesi Selatan

\begin{tabular}{|c|c|c|}
\hline Peubah & Musim hujan & Musim kemarau \\
\hline Suhu $\left({ }^{\circ} \mathrm{C}\right)$ & 31,4 & 32,2 \\
\hline Salinitas (ppt) & 18 & 31 \\
\hline Oksigen terlarut (mg/L) & 4,55 & 4,26 \\
\hline $\mathrm{pH}$ & 8,32 & 8,32 \\
\hline Bahan organik total (mg/L) & 3,45 & 6,22 \\
\hline $\mathrm{NH}_{4}(\mathrm{mg} / \mathrm{L})$ & 0,0426 & 0,0163 \\
\hline $\mathrm{NO}_{3}(\mathrm{mg} / \mathrm{L})$ & 0,0109 & 0,0045 \\
\hline $\mathrm{NO}_{2}(\mathrm{mg} / \mathrm{L})$ & 0,0075 & 0,0002 \\
\hline $\mathrm{PO}_{4}(\mathrm{mg} / \mathrm{L})$ & 0,0063 & 0,0046 \\
\hline $\mathrm{Fe}(\mathrm{mg} / \mathrm{L})$ & 0,0512 & 0,0059 \\
\hline $\mathrm{SO}_{4}(\mathrm{mg} / \mathrm{L})$ & 24,82 & 345,13 \\
\hline $\mathrm{SiO}_{2}(\mathrm{mg} / \mathrm{L})$ & 0,0424 & 0,1491 \\
\hline Kesadahan total (mg/L) & 171 & 685 \\
\hline
\end{tabular}

Sumber: Mustafa et al. (2007)

salinitas, bahan organik total dan kesadahan total air lebih tinggi dari pada musim hujan. Diduga kondisi musim kemarau lebih sesuai dengan kebutuhan lingkungan bagi teripang pasir, terutama salinitas. Sutaman (1993) menyatakan kualitas air yang harus dipenuhi dalam budidaya teripang pasir adalah: suhu antara $22^{\circ} \mathrm{C}$ dan $32^{\circ} \mathrm{C}$; salinitas antara 26 dan 33 ppt; oksigen terlarut antara 4,0 dan 8,0 mg/L; dan pH antara 7,5 dan 8,6.

Sampai tahun 2005, luas tambak di pantai timur Provinsi Sulawesi Selatan mencapai 42.839 ha (Anonim, 2005). Tambak tersebut tersebar di Kabupaten Luwu 
Timur, Luwu Utara, Luwu, Wajo, Bone, dan Sinjai serta Kota Palopo dengan luas masing-masing berturut-turut 5.441, 7.628, 4.408, 12.988, 10.810, 678, dan 916 ha. Tambak tersebut umumnya didominasi oleh tanah sulfat masam, tanah gambut dan tanah sulfat masam yang berasosiasi dengan tanah gambut. Dengan demikian, tambak di pantai timur Sulawesi Selatan berpotensi sebagai lahan budidaya teripang pasir, terutama di sekitar pantai yang memiliki salinitas yang relatif tinggi.

Tambak tanah sulfat masam yang berasosiasi dengan tanah gambut secara rasional sangat cocok untuk pengembangan budidaya teripang. Untuk pengembangan budidaya teripang di tambak tersebut mempunyai prospek yang cukup cerah, karena di samping didukung oleh masih luasnya tambak tanah sulfat masam, tanah gambut dan tanah sulfat masam yang berasosiasi dengan tanah gambut juga kurang dimanfaatkannya oleh pemiliknya, yang umumnya tambak-tambak gambuk tersebut terletak di wilayah pesisir dan mempunyai sumber air yang memadai terutama di Kabupaten Lutra.

Teripang pasir merupakan hewan laut yang mempunyai sifat biologi yaitu pergerakan lamban, senang menenggelamkan diri dalam lumpur terutama pada siang hari, bersifat filter feeder, relatif tahan hidup dan tumbuh pada tingkat kepadatan tinggi. Di laut teripang ukuran benih hingga teripang muda hidup pada perairan pantai dengan dasar bersubstrat pasir berlumpur atau lumpur berpasir yang ditumbuhi padang lamun dengan kedalaman air yang relatif dangkal (Daud et al., 1994). Teripang dewasa (500--2.000 g/ekor) hidup pada perairan yang bersubtrat lumpur dengan kedalaman air lebih 6 m (Daud et al., 1994).

Untuk budidaya teripang pasir di tambak terutama di tambak tanah sulfat masam yang berasosiasi dengan tanah gambut, maka sifat biologi yang dapat menjadi acuan adalah cara makannya, walaupun sebenarnya makanan utama teripang adalah plankton terutama diatom, tetapi dapat juga memanfaatkan pakan tambahan seperti pelet (Purwatiningsih \& Ambariyanto, 2003).

Teknik budidaya teripang di tambak pada perinsipnya sama saja pada budidaya ikan bandeng dan udang. Untuk mencapai pertumbuhan dan sintasan yang optimal dipilih tambak yang bersubstrat pasir berlempung yang kaya bahan organik seperti pada tambak tanah sulfat masam yang berasosiasi dengan tanah gambut dan konstruksi tambak dilengkapi pintu pemasukan dan pembuangan air. Hal ini sangat penting oleh karena budidaya teripang di tambak perlu sering dilakukan pengantian air, bahkan sangat sesuai bila dibudidayakan pada wadah dengan sistem air mengalir atau sistem resirkulasi (Purwatiningsih \& Ambariyanto, 2003).
Tingkat penebaran yang baku untuk budidaya teripang di tambak sampai saat ini belum ada patokan. Namun sebagai dasar dapat diaplikasikan padat tebar yang biasa dilakukan pada budidaya teripang dengan sistem kurungan tancap di laut 3--5 ekor/m² (Pirzan \& Tangko, 1990). Pakan yang diberikan berupa tepung klekap dan dedak halus, di samping sering dilakukan pemupukan susulan untuk menumbuhkan pakan alami seperti diatom dan klekap. Frekuensi pemberian pakan dilakukan 2 kali sehari yaitu pada pagi dan sore hari dengan dosis sebanyak $2 \%$ dari bobot biomassa. Masa pemeliharaan yang ideal yaitu selama 4--6 bulan dan tergantung dari ukuran bibit yang ditebar.

Setelah teripang mencapai ukuran konsumsi (300--500 g/ekor) dilakukan pemanenan dengan sistem bertahap karena teripang senang menenggelamkan diri dalam lumpur terutama pada siang hari. Pada hari pertama panen tambak dikeringkan kemudian teripang dipungut dengan tangan, setelah tidak ditemukan teripang lagi tambak diisi air kembali seadanya kemudian ditinggalkan dan pada esok harinya dipanen lagi begitu seterusnya sampai betul-betul bersih.

\section{KESIMPULAN}

1. Restocking merupakan metode yang efektif untuk mempertahankan produksi dan kelestarian sumber daya teripang pasir di alam. Metode ini tidak memerlukan biaya dan tenaga, kecuali hanya biaya pembelian benih yang akan ditebar.

2. Budidayanya teripang di tambak dapat meningkatan produksi sekaligus membuka lapangan keja baru bagi pembudidaya tambak, yang akhirnya dapat meningkatkan kesejahteraan.

3. Untuk pengembangan budidaya teripang di tambak paling tepat bila dilakukan pada tambak tanah sulfat masam yang berasosiasi tanah gambut, karena berdasarkan pengamatan di lapangan teripang pasir yang ditemukan di tambak tersebut cukup besar yaitu mencapai 300--500 g/ekor.

4. Peluang dan prospek pengembangan budidaya teripang pada tambak tanah sulfat masam berasosiasi tanah gambut cukup besar, karena di Sulawesi Selatan terdapat sekitar 42.839 ha tambak yang didominasi oleh tambak jenis tanah tersebut yang kebanyakan tidak berproduksi dan ditelantarkan oleh pemiliknya.

\section{DAFTAR PUSTAKA}

Anonim. 2005. Laporan Statistik Perikanan Sulawesi Selatan. 2002. Dinas Perikanan dan Kelautan Propinsi Sulawesi Selatan, Makassar. 261 pp. 
Anonim. 2007. Statistik Perikanan Tangkap 2006. Dinas Perikanan dan Kelautan Provinsi Sulawesi Selatan. Makassar. 50 pp.

Aström, M. 1998. Mobility of Al, P and alkaline earth metals in acid sulphate soil in Finland. The Science of the Total Environment. 215: 19-30.

Boyd, C.E. 1995. Bottom Soils, Sediment and Pond Aquaculture. Chapman \& Hall, New York. 347 pp.

Cowx, I.G. 1998. An appraisal of stocking strategies in the light of developing country constraints. In: Petr, T. (ed.), Inland Fishery Enhancements. Papers presented at the FAO/DFID. Expert consultation on inland fishery enhancement. Dhaka, Bangladesh, 7-11 April 1997. FAO Fish. Tech. Pap. No. 374. Rome. p. $119-132$.

Daud, R., A.M. Tangko, dan A. Sudradjat. 1994. Pengaruh substrat terhadap pertumbuhan dan kelangsungan hidup teripang putih (Holothuria scabra). Warta Balitdita. 6(1): 15- 17.

Dent, D.L. 1986. Acid Sulphate Soils: A Baseline for Research and Development. ILRI Publication 39. International Institute for Land Reclamation and Improvement, Wageningen. 204 pp.
Mustafa, A. and J. Sammut. 2007. Effect of different remediation techniques and dosages of phosphorus fertilizer on soil quality and klekap production in acid sulfate soil affected aquaculture ponds. Indonesian Aquaculture Journal. 2(2): 141- 157.

Mustafa, A., M. Paena, Hasnawi, A.M. Pirzan, E. Ratna, A.M. Tangko, R. Sabang, Sutrisyani, Darsono, Kamariah, Rahmiyah, dan Haking. 2007a. Validasi dan Kesesuaian Lahan Tambak di Kab. Luwu Utara Propinsi Sulawesi Selatan. Laporan teknis Balai Riset Perikanan Budidaya Air Payau, Maros. 123 pp.

Pirzan, A.M. dan A.M. Tangko. 1990. Budidaya teripang dalam kurungan. Warta Balitdita. 2(2), 24-26.

Purnomo, K., S. Koeshendrajana, dan E.S. Kartamihardja 2001. Konsep Peningkatan Stok di Perairan Waduk Dan Danau. Warta Penelitian Perikanan Indonesia. 7(2): 15-18.

Purwatiningsih dan Ambariyanto. 2003. Kelimpahan Teripang (Holothuria sp.) di Pantai Bondo dan Bandengan, Jepara Indonesia. Sains Akuatik Jurnal IImuilmu Perairan, 6(1): 1-6.

Sutaman. 1993. Petunjuk Praktis Budidaya Teripang. Penerbit Kanisius, Yogyakarta. 68 pp. 